\title{
INVESTIGATION OF ANTIBIOTIC SUSCEPTIBILITY OF THE BACTERIAL ISOLATES AND LOCAL FLORA CHANGES AFTER COMPLEX THERAPY IN CHRONIC PERIODONTITIS AND PERIIMPLANTITIS
}

\author{
LIDIA CIOBANU $^{1 \#}$, GABRIELA BĂNCESCU $^{1 * *}$, ANDREEA CRISTIANA DIDILESCU $^{2 *}$, \\ ADRIAN ANTON BĂNCESCU ${ }^{3 \#}$
}

\begin{abstract}
${ }^{I}$ Department of Microbiology, Faculty of Dental Medicine, "Carol Davila" University of Medicine and Pharmacy, Bucharest, Romania ${ }^{2}$ Department of Embryology, Faculty of Dental Medicine, "Carol Davila" University of Medicine and Pharmacy, Bucharest, Romania

${ }^{3}$ Department of Epidemiology, Faculty of Medicine, "Carol Davila" University of Medicine and Pharmacy, Bucharest, Romania
\end{abstract}

*corresponding author: gabi.bancescu@gmail.com

\#All authors have equal contribution

Manuscript received: June 2018

\begin{abstract}
The aim of the study was to test the antibiotic susceptibility of the subgingival biofilm (SGBF) isolates from chronic periodontitis (PD) and periimplantitis (PI) sites, and to investigate the changes of local flora after complex therapy including, amoxicillin-clavulanate $(\mathrm{XL})$. SGBF from periodontal pocket $(A$ sample) and around the dental implant $(B$ sample) was collected before $\left(t_{l}\right)$ and after $\left(t_{2}\right)$ therapy. Gram smears and cultures on blood media were done. E-test was used for the antibiotic susceptibility testing. The smears indicated at $t_{2}$ a significant decrease of polymorphonuclears number and microbial load with marked reduction of spirochetes and Gram-negative bacilli number. In $A$ sample, $P$. intermedia and Capnocytophaga predominated at $t_{l}$ and $S$. oralis at $t_{2}$, while in $B$ sample, Capnocytophaga predominated at $t_{I}$ and $S$. mitis at $t_{2}$. All except 2 isolates (not recovered at $t_{2}$ ) were XL-susceptible. The clinical and microbiological findings showed local status improvement at $t_{2}$. The antibiogram is helpful when antibiotics are needed in PD/PI therapy.
\end{abstract}

\section{Rezumat}

Scopul studiului a fost testarea sensibilităţii la antibiotice a izolatelor din biofilmul subgingival (BFSG) al situsurilor cu parodontită marginală cronică (PD) şi periimplantită (PI) și investigarea modificării florei locale după terapia complexă, incluzând amoxicilină-clavulanate (XL). S-a recoltat BFSG de la nivelul pungii parodontale şi din jurul implantului dentar (probele $A$ şi $B$ ), înainte $\left(t_{1}\right)$ şi după $\left(t_{2}\right)$ terapie. S-au făcut frotiuri Gram şi însămânţări pe medii cu sânge. Sensibilitatea tulpinilor la antibiotice a fost investigată prin E-test. La $t_{2}$, frotiurile au arătat o scădere semnificativă a polimorfonuclearelor și a încărcăturii microbiene, cu reducerea marcantă a numărului de spirochete și bacili Gram-negativi. În proba $A$ au predominat $P$. intermedia şi Capnocytophaga la $t_{l}$ şi $S$. oralis la $t_{2}$, iar în proba $B$, Capnocytophaga la $t_{l}$ şi $S$. mitis la $t_{2}$. Izolatele au fost sensibile la XL, exceptând 2 tulpini neizolate la $t_{2}$. Constatările clinico-microbiologice au indicat îmbunătăţirea statusului local la t2. Antibiograma este necesară când antibioterapia se impune în PD/PI.

Keywords: antibiotic susceptibility, periodontitis, periimplantitis

\section{Introduction}

In the human body most bacteria are organized in biofilms, which may be involved in many infections, when local homeostasis breaks down $[4,7,17,19]$. The subgingival biofilm (SGBF) is the main factor incriminated in the appearance and evolution of chronic periodontitis (PD), but a susceptible host is essential [28]. PD is an inflammatory disease leading to destruction of the teeth supporting tissues [14]. The ecological plaque hypothesis states that periodontal disease occurs as a consequence of an exaggerated host inflammatory response towards a subgingival dysbiosis induced by the local environment changes [21]. Periodontal disease may have a large manifestation area, starting from gingival tissues affection up to destruction of periodontium and in certain cases may lead even to tooth loss [20, 22]. Nowadays, dental implant became a current choice in the treatment of missing teeth [32]. However, serious complications might appear and it is estimated that after 10 years, periimplant mucositis (inflammation of the implant soft tissue) affect $63 \%$ of patients and $31 \%$ of implants, while periimplantitis (PI), inflammatory process affecting the soft tissue and surrounding bone of the implant, affect $19 \%$ of patients and $10 \%$ of implants [3]. PI onset is mainly the consequence of an imbalance occurred between microbial load and host defence factors [34]. PI is generally associated with PD history, 
smoking, systemic diseases or iatrogenic factors. Since in vitro antimicrobial susceptibility testing is not usually done in current practice [30], antibiotics are often given empirically when PD and PI require treatment with such drugs.

In Romania, only few data have been published regarding the susceptibility of bacteria isolated from oral infections $[5,6]$. The aim of this study was the susceptibility testing against amoxicillin-clavulanate (XL) and other 5 commonly used antibiotics of the isolates from SGBF samples in both PD and PI. In addition, the changes in local flora profile were investigated after combined surgical and non-surgical treatment, including administration of systemic antibiotic.

\section{Materials and Methods}

The samples for this microbiological investigation were provided from sites with chronic periodontitis and periimplantitis, before and after complex therapy. Patient's informed consent was obtained. The samples received at time $1(t 1)$ were collected before treatment and the samples received at time 2 ( $t 2)$ were collected at the end of one month of combined therapy (scaling and root planning, antibiotic treatment with XL $1000 \mathrm{mg}$ for 10 days, anti-inflammatory treatment with prednisone $5 \mathrm{mg}$ for one month).

SGBF samples were collected by calibrated loop $(0.001 \mathrm{~mL})$ from the deepest periodontal pocket $(A$ sample), and around the implant ( $B$ sample), at $t_{l}$ and $t_{2}$. Glass slide smears and seeding on: Columbia agar with 5\% sheep blood (COS) (BioMérieux, France), chocolate agar with PolyViteX (PVX) (BioMérieux, France), Schedler agar with 5\% sheep blood, hemin and vitamin K3 (SCS) (BioMérieux, France), and selective Schaedler agar with neomycin and vancomycin (SNVS) (BioMérieux, France), were performed chair side from $A$ and $B$ sample. The $0.001 \mathrm{~mL}$ inoculum was discharged on SCS and spread on the surface by another loop, while the remained material on the collecting loop was spread on COS, PVX and SNVS. SCS and SNVS were introduced into a jar (GENbox) (BioMérieux, France) with an anaerobic atmosphere generator sachet (GENbox anaer sachet) (BioMérieux, France) and anaerobic indicator strip (Anaer indicator) (BioMérieux, France), while COS and PVX were put into a GENbox with a $\mathrm{CO}_{2}$ sachet (GENbox $\mathrm{CO}_{2}$ sachet) (BioMérieux, France). The jars and glass slide smears were transported within half an hour to the laboratory of the Microbiology Discipline, Faculty of Dental Medicine, "Carol Davila" University of Medicine and Pharmacy, Bucharest, where the jars were incubated at $35^{\circ} \mathrm{C}$ and the smears were stained by Gram's method. COS and PVX were incubated for $48 \mathrm{~h}$, with first examination at $24 \mathrm{~h}$, while SCS and SNVS were incubated for 10 days, with culture examination every $48 \mathrm{~h}$. All the isolates were identified at genus or species level by conventional microbiological methods and by the Rapid ID 32 STREP, Rapid ID 32 A or Api NH system (BioMérieux, France). In addition, the Slidex Strepto Plus kit (BioMérieux, France) was used for serogrouping the streptococcal strains belonging to anginosus group and MAST ID XV MIRROR RING (Mast Group Ltd., U.K.) for searching the growth factors requirement of Haemophilus isolates.

The semi-quantitative bacterial growth appreciation on SCS (performed at $48 \mathrm{~h}$ and revised every $48 \mathrm{~h}$ during the whole incubation period) was based on the following arbitrary $1-4+$ score scale: 0 for no colony, 1+ for 1 - 10 colonies, 2+ for 11 - 50 colonies, $3+$ for $51-100$ colonies and $4+$ for more than 100 colonies.

The isolates were tested against: penicillin $\mathrm{G}(\mathrm{PG})$, ampicillin (AM), XL, clindamycin (CM), tetracycline (TC) and metronidazole (MZ) by Etest (BioMérieux, France). The antibiograms were done on: Brucella blood agar (BBA) (BioMérieux, France) for Capnocytophaga spp. and anaerobes, including Actinomyces isolates, Müller-Hinton agar with 5\% sheep blood (MHS) (BioMérieux, France) for streptococcal and Neisseria isolates, and Haemophilus test medium (HTM) (Becton Dickinson $\mathrm{GmbH}$, Germany) for Haemophilus isolates. The BBA plates were seeded by swab with the inoculum prepared in broth and adjusted to the turbidity of 0.5 or $1 \mathrm{McF}$ arland standard (according to the instructions given by the manufacturer for the respective bacterial isolate). After placing the E-test strips onto the seeded media, the plates were anaerobically incubated at $35^{\circ} \mathrm{C}$ for $48-72 \mathrm{~h}$, while HTM and MHS plates were incubated in $5 \% \mathrm{CO}_{2}$ atmosphere at $35^{\circ} \mathrm{C}$ for $24 \mathrm{~h}$. The quality controls were: Streptococcus pneumoniae ATCC 49619, Haemophilus influenzae ATCC 49247, Bacteroides fragilis ATCC 25285 and Bacteroides thetaiotaomicron ATCC 29741. The minimum inhibitory concentration (MIC) was interpreted as indicated by Clinical and Laboratory Standards Institute (CLSI) [11]. The Cefinase-test (BioMérieux, France) was applied on the putative beta-lactamase producers, while the streptococcal isolates were checked for inducible CM resistance by the double disk test (the "D" test), using $15 \mu \mathrm{g}$ erythromycin (EM) and $2 \mu \mathrm{g} \mathrm{CM}$ disks (Oxoid, UK).

\section{Results and Discussion}

$A$ and $B$ smears at $t_{l}$ showed a huge number of: polymorphonuclear leukocytes, spiral-shaped bacteria, Gram-negative coccobacilli, fusiform and rounded ends bacilli, and Gram-positive cocci in diplo and chains. The $A$ smear presented Gram-negative reniforme diplococci in small number and moderate Grampositive filamentous bacteria, while the $B$ smear showed also Gram-negative reniforme diplococci in high 
FARMACIA, 2018, Vol. 66, 6

number, but only few Gram-positive filamentous bacteria. At $t_{2}$, the $A$ smear showed very few leukocytes, lack of spirochetes, high number of Grampositive cocci (mostly in chains) and rods, and moderate Gram-negative bacilli and coccobacilli, while $B$ smear showed moderate leukocytes and spirochetes, but high number of: Gram-negative coccobacilli/bacilli, Gram-positive cocci (single, in diplo and chains) and Gram-negative reniforme diplococci. The Gram smears indicated at $t_{2}$ a significant decrease of the number of leukocytes, spirochetes, fusiforms and Gram-negative cocobacilli/ bacilii with rounded ends.

Table I

Culture findings of the subgingival biofilm samples

\begin{tabular}{|c|c|c|c|c|}
\hline \multirow{2}{*}{ Sample } & \multicolumn{2}{|c|}{ Culture results before therapy } & \multicolumn{2}{|c|}{ Culture results after therapy } \\
\hline & Isolates & Growth score $^{\mathrm{a}}$ on SCS $\mathrm{SC}^{\mathrm{b}}$ & Isolates & Growth score on SCS \\
\hline $\begin{array}{l}\mathrm{SGBF}^{\mathrm{c}} \text { from the deepest } \\
\text { periodontal pocket }\end{array}$ & $\begin{array}{c}\text { P. intermedia } \\
\text { Capnocytophaga spp. } \\
\text { S. constellatus } \\
\text { S. mitis } \\
\text { S. sanguinis } \\
\text { A. viscosus }\end{array}$ & $\begin{array}{l}3+ \\
3+ \\
2+ \\
2+ \\
2+ \\
1+\end{array}$ & $\begin{array}{c}\text { P. intermedia } \\
\text { P. buccae } \\
\text { S. anginosus (F group) } \\
\text { S. oralis }\end{array}$ & $\begin{array}{l}1+ \\
2+ \\
1+ \\
3+\end{array}$ \\
\hline $\begin{array}{l}\text { SGBF around dental } \\
\text { implant }\end{array}$ & $\begin{array}{c}\text { Capnocytophaga spp. } \\
\text { P. oralis } \\
\text { S. intermedius } \\
\text { S. gordonii } \\
\text { H. parainfluenzae } \\
\text { Veillonella } \text { spp. }\end{array}$ & $\begin{array}{l}+ \\
2+ \\
2+ \\
2+ \\
0 \\
1+\end{array}$ & $\begin{array}{c}\text { P. buccae } \\
\text { S. constellatus (C group) } \\
\text { S. mitis } \\
\text { N. mucosa }\end{array}$ & $\begin{array}{c}2+ \\
1+ \\
3+ \\
0\end{array}$ \\
\hline
\end{tabular}

${ }^{a}$ Score of: 0 for no colony, 1+ for 1 - 10 colonies, 2+ for 11 - 50 colonies, 3+ for 51 - 100 colonies and 4+ for more than 100 colonies; ${ }^{b}$ nonselective Schaedler agar; ${ }^{c}$ subgingival biofilm; ${ }^{\mathrm{d}}$ species isolated only from the primary Columbia blood agar and chocolate agar; ${ }^{\mathrm{e}}$ species isolated only from the primary chocolate agar

Table II

The minimum inhibitory concentrations of the tested antibiotics and beta-lactamase production of the strains isolated from the subgingival biofilm samples

\begin{tabular}{|c|c|c|c|c|c|c|c|c|c|}
\hline \multirow{2}{*}{\multicolumn{2}{|c|}{ Origin of the isolates }} & \multirow{2}{*}{ Isolates } & \multicolumn{6}{|c|}{$\mathrm{MIC}^{\mathrm{a}}(\mathrm{mg} / \mathrm{L})$ [interpretation of susceptibility] } & \multirow[t]{2}{*}{ Beta-lacta-mase } \\
\hline & & & $\mathrm{PG}^{\mathrm{b}}$ & $\mathrm{AM}^{\mathrm{c}}$ & $\mathrm{XL}^{\mathrm{d}}$ & $\mathrm{CM}^{\mathrm{e}}$ & $\mathrm{TC}^{\mathrm{f}}$ & $\mathrm{MZ}^{\mathrm{g}}$ & \\
\hline \multirow{10}{*}{$\begin{array}{l}\mathrm{SGBF}^{\mathrm{h}} \\
\text { from the } \\
\text { deepest } \\
\text { peri- } \\
\text { odontal } \\
\text { pocket }\end{array}$} & \multirow{6}{*}{$\begin{array}{l}\text { Before } \\
\text { therapy }\end{array}$} & P. intermedia & $1.5\left[\mathrm{I}^{\mathrm{i}}\right]$ & $1[\mathrm{I}]$ & $0.064\left[\mathrm{~S}^{j}\right]$ & $0.016[\mathrm{~S}]$ & $2[\mathrm{~S}]$ & $0.016[\mathrm{~S}]$ & $+^{\mathrm{k}}$ \\
\hline & & Capnocytophaga & $0.064[\mathrm{~S}]$ & $0.019[\mathrm{~S}]$ & $0.019[\mathrm{~S}]$ & $0.016[\mathrm{~S}]$ & $0.094[\mathrm{~S}]$ & $\mathrm{NT}^{\mathrm{l}}$ & $-m$ \\
\hline & & S. constellatus & $0.023[\mathrm{~S}]$ & $0.125[\mathrm{~S}]$ & NT & $0.064[\mathrm{~S}]$ & $0.75[\mathrm{~S}]$ & NT & NT \\
\hline & & S. mitis & $2[\mathrm{I}]$ & $1,5[\mathrm{I}]$ & NT & $0.023[\mathrm{~S}]$ & $0.75[\mathrm{~S}]$ & NT & NT \\
\hline & & S. sanguinis & $1[\mathrm{I}]$ & 1 [I] & NT & $0.023[\mathrm{~S}]$ & $3[\mathrm{I}]$ & NT & NT \\
\hline & & A. $v i$ & 0.094 [S] & $0.064[\mathrm{~S}]$ & $0.064[\mathrm{~S}]$ & $0.016[\mathrm{~S}]$ & $0.38[\mathrm{~S}]$ & $>256\left[\mathrm{R}^{\mathrm{n}}\right]$ & 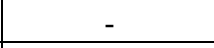 \\
\hline & \multirow{4}{*}{$\begin{array}{l}\text { After } \\
\text { therapy }\end{array}$} & P. intermedia & $2[\mathrm{R}]$ & $1,5[\mathrm{I}]$ & $0.064[\mathrm{~S}]$ & $0.016[\mathrm{~S}]$ & $2[\mathrm{~S}]$ & $0.016[\mathrm{~S}]$ & + \\
\hline & & P. buccae & $0.38[\mathrm{~S}]$ & $0.25[\mathrm{~S}]$ & $0.25[\mathrm{~S}]$ & $0.016[\mathrm{~S}]$ & $0.125[\mathrm{~S}]$ & $0.016[\mathrm{~S}]$ & - \\
\hline & & S. anginosus & $0.047[\mathrm{~S}]$ & $0.094[\mathrm{~S}]$ & NT & $0.094[\mathrm{~S}]$ & $4[\mathrm{I}]$ & NT & NT \\
\hline & & S. oralis & $0.75[\mathrm{~S}]$ & $0.094[\mathrm{~S}]$ & NT & $0.064[\mathrm{~S}]$ & $0.125[\mathrm{~S}]$ & NT & NT \\
\hline \multirow{10}{*}{$\begin{array}{c}\text { SGBF } \\
\text { around } \\
\text { dental } \\
\text { implant }\end{array}$} & \multirow{6}{*}{$\begin{array}{l}\text { Before } \\
\text { therapy }\end{array}$} & Capnocytophaga & $0.047[\mathrm{~S}]$ & $0.064[\mathrm{~S}]$ & $0.064[\mathrm{~S}]$ & $0.016[\mathrm{~S}]$ & $0.064[\mathrm{~S}]$ & NT & - \\
\hline & & P. oralis & $0.023[\mathrm{~S}]$ & 0.023 [S] & $0.023[\mathrm{~S}]$ & $0.016[\mathrm{~S}]$ & $0.125[\mathrm{~S}]$ & $0.016[\mathrm{~S}]$ & - \\
\hline & & S. intermedius & $0.016[\mathrm{~S}]$ & $0.016[\mathrm{~S}]$ & NT & $0.016[\mathrm{~S}]$ & 0.19 [S] & NT & NT \\
\hline & & S. gordonii & $0.064[\mathrm{~S}]$ & $0.094[\mathrm{~S}]$ & NT & $0.064[\mathrm{~S}]$ & $0.50[\mathrm{~S}]$ & NT & NT \\
\hline & & H. parainfluenzae & NT & $24[\mathrm{R}]$ & $0.75[\mathrm{~S}]$ & NT & $1[\mathrm{~S}]$ & NT & + \\
\hline & & Veillonella & $0.023[\mathrm{~S}]$ & $0.023[\mathrm{~S}]$ & $0.023[\mathrm{~S}]$ & $0.016[\mathrm{~S}]$ & $0.19[\mathrm{~S}]$ & $0.064[\mathrm{~S}]$ & - \\
\hline & \multirow{4}{*}{$\begin{array}{l}\text { After } \\
\text { therapy }\end{array}$} & P. buccae & $0.023[\mathrm{~S}]$ & $0.064[\mathrm{~S}]$ & $0.064[\mathrm{~S}]$ & 0.016 [S] & 0.125 [S] & $0.094[\mathrm{~S}]$ & - \\
\hline & & S. constellatus & $0.064[\mathrm{~S}]$ & $0.125[\mathrm{~S}]$ & NT & $0.125[\mathrm{~S}]$ & $0.094[\mathrm{~S}]$ & NT & NT \\
\hline & & S. mitis & $0.047[\mathrm{~S}]$ & $0.016[\mathrm{~S}]$ & NT & $0.094[\mathrm{~S}]$ & $0.125[\mathrm{~S}]$ & NT & NT \\
\hline & & N. mucosa & $0.094[\mathrm{~S}]$ & $0.064[\mathrm{~S}]$ & $0.064[\mathrm{~S}]$ & $96[\mathrm{R}]$ & $3[\mathrm{I}]$ & NT & 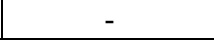 \\
\hline
\end{tabular}

${ }^{\mathrm{a}} \mathrm{MIC}=$ minimum inhibitory concentration, ${ }^{\mathrm{b}} \mathrm{PG}=$ penicillin $\mathrm{G},{ }^{\mathrm{c}} \mathrm{AM}=$ ampicillin, ${ }^{\mathrm{d}} \mathrm{XL}=$ amoxicillin-clavulanate,${ }^{\mathrm{e}} \mathrm{CM}=$ clindamycin, ${ }^{\mathrm{f}} \mathrm{TC}=$ tetracycline,${ }^{\mathrm{g}} \mathrm{MZ}=$ metronidazole, ${ }^{\mathrm{h}} \mathrm{SGBF}=$ subgingival biofilm; ${ }^{\mathrm{i}} \mathrm{I}=$ intermediate susceptible, ${ }^{\mathrm{j}} \mathrm{S}=$ susceptible,${ }^{\mathrm{k}}+=$ beta-lactamase positive, ${ }^{1} \mathrm{NT}=$ not tested (not recommended to be tested); ${ }^{\mathrm{m}}$ - = beta-lactamase negative, ${ }^{\mathrm{n}} \mathrm{R}=$ resistant.

Mixed cultures were obtained from all samples and the results indicated a significant shift in the local flora profile at $t_{2}$ compared to $t_{1}$ (Table I). As expected, the colonies of Actinomyces viscosus became visible after one week of anaerobic incubation. Neisseria mucosa was isolated only from COS ( 9 colonies) and
PVX (11 colonies), while Haemophilus parainfluenzae only from PVX, in scanty growth (4 colonies).

The Capnocytophaga spp. strains were isolated from SCS in very heavy growth, but not from the primary PVX, incubated in $5 \% \mathrm{CO}_{2}$ atmosphere for $48 \mathrm{~h}$. However, these isolates were further sub-cultivated on PVX in $5 \% \mathrm{CO}_{2}$ atmosphere and grew properly. 
FARMACIA, 2018, Vol. 66, 6

Capnocytophaga spp. and Prevotella intermedia predominated (score $3+$ ) in $A$ sample at $t_{l}$, while at $t_{2}$ the first were not isolated and the latter grew extremely scanty (2 colonies). Capnocytophaga was by far the predominant bacteria (score $4+$ ) isolated from $B$ sample at $t_{1}$, without being recovered at $t_{2}$. The antibiograms data are mentioned in Table II, together with the results of beta-lactamase detection (Table II). Besides the beta-lactam antibiotics, the isolates were tested against other 3 drugs of different families, chosen as alternative to XL therapy.

$\mathrm{XL}$ was active against all the isolates except for Streptococcus mitis and Streptococcus sanguinis strains from $A$ sample, which expressed PG- and AM-reduced susceptibility, and being implicitly XL-intermediate susceptible. S. mitis was the only streptococcal strain found with EM-reduced susceptibility and displayed the M phenotype. S. mitis and $S$. sanguinis showed a growth score of $2+$ at $t_{1}$ but were not isolated anymore at $t_{2}$.

Of the isolates tested for beta-lactamase production only $P$. intermedia and $H$. parainfluenzae strains showed positive results and were reported as AMand PG- resistant. $P$. intermedia was isolated in extremely scanty growth (2 colonies on SCS) at $t_{2}$ and it was noticed a slightly increase of PG- and AM-MIC values.

N. mucosa is a commensal oral microorganism but may produce infections in immunocompromised patients. Since there are not accepted criteria for antimicrobial susceptibility evaluation of $N$. mucosa, the MIC values of this bacterial isolates were orientatively interpreted based on the CLSI breakpoints for Moraxella catarrhalis (previously known as Neisserial Branhamella catarrhalis) [12]. The N. mucosa strain was susceptible to the beta-lactam antibiotics, but highly CM-resistant. CM was active against the other isolates but not the Haemophilus isolate, due to its intrinsic resistance.

The isolates were TC-susceptible except for S. sanguinis, Streptococcus anginosus and most likely for $N$. mucosa too, which presented reduced susceptibility. MZ was fully active against the anaerobic isolates apart from $A$. viscosus, which is actually a facultative anaerobe. However, several studies reported MZsusceptible Actinomyces isolates [15, 35].

Capnocytophaga isolates were considered to be susceptible to all 6 antibiotics tested, by comparing their MIC values to CLSI breakpoints indicated for the group of the following bacteria: Haemophilus, Aggregatibacter, Cardiobacterium, Eikenella and Kingella (HACEK group), known at present as the group of: Aggregatibacter aphrophilus (formerly Haemophilus aphrophilus), Aggregatibacter, Actinomycetemcomitans, Cardiobacterium hominis, Eikenella corrodens and Kingella kingae (AACEK group) [2].
Many studies have been focused on the efficacy of various periodontal therapy methods in improving the clinical periodontal parameters. However, several studies have investigated the subgingival microbiota changes due to periodontal therapy and their results have indicated that the decrease in frequency, levels and proportions of the periodontal pathogenic bacteria was accompanied by the clinical improvement [1, $26,29,31]$. The present study indicated also the reduction of the periodontal pathogenic bacteria, although the microbiological investigation was limited at one month after therapy. Like in the findings of Socransky et al [31], S. oralis was the only bacteria found in a high level after periodontal treatment.

Capnocytophaga spp. are members of the normal oral flora, but may produce oral or systemic infections too. These bacteria were isolated from SGBF in healthy periodontium, but from PD too [8, 23, 24], and sometimes in heavy growth [33].

In the present study Capnocytophaga was found at a high level at $t_{l}$ and this is in agreement with other authors who reported an increased prevalence of this microorganism in periodontal disease [18, 27]. Several scientific papers have also shown a high prevalence of Capnocytophaga spp. in diabetic patients with gingivitis or periodontitis $[9,10,25]$. Ehrmann et al reported that the rate of this microorganism isolation among the patients investigated (including 11 periodontitis patients) was $100 \%$ [13]. The same authors found that $44 \%$ of the subgingival isolates of Capnocytophaga were beta-lactamase positive, while Capnocytophaga strains isolated during the present study were beta-lactamase negative.

In contrast to this study data, Handal et al reported Capnocytophaga isolates of oral origin with high resistance (MIC $\geq 256 \mathrm{mg} / \mathrm{L}$ ) against: amoxicillin, ceftazidime, cefotaxime, cefuroxime, EM, CM and TC [16]. It was found that $c f x A 2$ and $c f x A 3$ genes were responsible for the extended spectrum betalactamase production in $80 \%$ of those isolates, while $\mathrm{XL}$ and ceftazidime-clavulanic acid were fully active [16].

The clinical examination at $t 2$ indicated a significant improvement of the local status: gingival reattachment, absence of bleeding on probing and lack of suppuration. In this study, all the isolates, either putative periodontal pathogens, like $P$. intermedia and $S$. constellatus (members of the orange complex associated with PD), or non-pathogenic bacteria, were tested against all 6 commonly used antibiotics. This allowed a larger view upon the antibiotic resistance among the isolates from PD and PI in dynamics. It is obviously that the combined therapy was focused on SGBF control and not SGBF elimination, in order to reestablish the normal local flora which is compatible with the periodontal and periimplant health status. 


\section{Conclusions}

The antibiogram indicated that XL was active against all the isolates, including the beta-lactamase producers, except for a couple of oral streptococcal isolates (not recoved at $t_{2}$ ). Sometimes Capnocytophaga spp. seems to be one of the main bacteria involved in PD and PI. The present findings suggest that anaerobic incubation should be performed too, when looking for primary isolation of this capnophilic microorganism. The microbiological and clinical data indicated marked local status improvement following the complex therapy, including XL administration. The antibiogram should be considered a helpful tool when antibiotics are required for PD and PI treatment.

\section{Acknowledgement}

This work was supported by the Sectorial Operational Programme Human Resources Development (SOP HRD), financed from the European Social Fund and by the Romanian Government under the contract number POSDRU/187/1.5/S/155463.

\section{References}

1. Aimetti M, Romano F, Guzzi N, Carnevale G, Onestage full-mouth disinfection as a therapeutic approach for generalized aggressive periodontitis. $J$ Periodontol., 2011; 82: 845-853

2. Arora H, McGrath E, Asmar BI, Infective Endocarditis. In: Sarnaik A, Ross R, Lipshultz S, Walters III H (eds). Cardiac Emergencies in Children. Cham: Springer, 2018: 303-314

3. Atieh MA, Alsabeeha NH, Faggion CMJr, Duncan WJ, The frequency of peri-implant diseases: a systematic review and metaanalysis. J Periodontol., 2013; 84: 1586-1598.

4. Bădiceanu CD, Nuță D, Missir AV, Hrubaru M, Delcaru C, Dițu LM, Chifiriuc MC, Limban C, Synthesis, structural, phisico-chemical characterization and antimicrobial activity screening of new thiourea derivatives. Farmacia, 2018; 66(1): 149-156.

5. Băncescu A, Băncescu G, Didilescu A, Hîrjău M, Antibiotic susceptibility testing of some Prevotella strains isolated from vestibular abscesses. Farmacia, 2017; 65(1): 132-135.

6. Băncescu G, Defta C, Băncescu A, Hîrjău M, The susceptibility to antibiotics of some Streptococcus constellatus strains isolated from odontogenic infections. Farmacia, 2016; 64(1): 58-60.

7. Belda-Ferre P, Alcaraz LD, Cabrera-Rubio R, Romero H, Simón-Soro A, Pignatelli M, Mira A, The oral metagenome in health and disease. ISME J., 2012; 6(1): 46-56.

8. Bonatti H, Rossoth DW, Nachbaur D, Fille M, Aspöck C, Hend I, Hourmont K, White L, Malnick H, A series of infections due to Capnocytophaga spp. in immunosuppressed and immunocompetent patients. Clin Microbiol Infect., 2003; 9(5): 380-387.

9. Casarin RC, Barbagallo A, Meulman T, Santos VR, Sallum EA, Nociti FH, Duarte PM, Casati MZ, Gonçalves RB, Subgingival biodiversity in subjects with uncontrolled type-2 diabetes and chronic periodontitis. J Periodontal Res., 2013; 48(1): 30-36.

10. Ciantar M, Gilthorpe MS, Hurel SJ, Newman HN, Wilson M, Spratt DA, Capnocytophaga spp. in periodontitis patients manifesting diabetes mellitus. J Periodontol., 2005; 76(2): 194-203.

11. Clinical and Laboratory Standards Institute (CLSI). M100S Performance standards for antimicrobial susceptibility testing, $26^{\text {th }}$ ed. Wayne, PA: Clinical and Laboratory Standards Institute, 2017.

12. Clinical and Laboratory Standards Institute (CLSI). Methods for antimicrobial dilution and disk susceptibility testing of infrequently isolated or fastidious bacteria. Approved standard M45-A. Wayne, PA: Clinical and Laboratory Standards Institute, 2006.

13. Ehrmann E, Handal T, Tamanai-Shacoori Z, Fosse T, High prevalence of $\beta$-lactam and macrolide resistance genes in human oral Capnocytophaga species. $J$ Antimicrob Chemother., 2014; 69(2): 381-384.

14. Ferreira MC, Dias-Pereira AC, Branco-de-Almeida LS, Martins CC, Paiva SM, Impact of periodontal disease on quality of life: a systematic review. $J$ Periodontal Res., 2017; 52 (4): 651-665.

15. Goldstein EJC, Citron DM, Merriam CV, Warren $\mathrm{Y}$, Tyrrell $\mathrm{K}$, Fernandez $\mathrm{H}$, In vitro activities of dalbavancin and nine comparator agents against anaerobic Gram-positive species and corynebacteria. Antimicrob Agents Chemother., 2003; 47(6): 19681971.

16. Handal T, Giraud-Morin C, Caugant DA, Madinier I, Olsen I, Fosse T, Chromosome- and plasmid-encoded $\beta$-lactamases in Capnocytophaga spp. Antimicrob Agents Chemother., 2005; 49(9): 3940-3943.

17. Hazem A, Popescu CV, Crișan I, Popa M, Chifiriuc MC, Gradișteanu Pircalabioru G, Lupuliasa D, Antibacterial efficiency of five propolis extracts on planktonic and adherent microbial strains. Farmacia, 2017; 65(5): 813-818.

18. Heller D, Silva-Boghossian CM, do Souto RM, Colombo AP, Subgingival microbial profiles of generalized aggressive and chronic periodontal diseases. Arch Oral Biol., 2012; 57(7): 973-980.

19. Jamal M, Ahmad W, Andleeb S, Jalil F, Imran M, Nawaz MA, Hussain T, Ali M, Rafiq M, Kamil M, Bacterial biofilm and associated infections. $J$ Chin Med Assoc., 2018; 81(1): 7-11.

20. Larsen T, Fiehn NE, Dental biofilm infections - an update. APMIS, 2017; 125(4): 376-384.

21. Marsh PD, Ecological events in oral health and disease: new opportunities for prevention and disease control?. $J$ Calif Dent Assoc., 2017; 45(10): 525-537.

22. Marsh PD, Lewis MAO, Rogers H, Williams DW, Wilson M, Marsh \& Martin's Oral microbiology, $6^{\text {th }}$ ed. Edinburgh: ELSEVIER, 2016: 112-158.

23. Newman MG, Socransky SS, Savitt ED, Propas DA, Crawford A, Studies of the microbiology of periodontosis. J Periodontol., 1976; 43: 373-379.

24. Peterson SN, Snesrud E, Liu J, Ong AC, Kilian M, Schork NJ, Bretz W, The dental plaque microbiome in health and disease. PLoS One, 2013; 8(3): 1-10.

25. Sakalauskiene J, Kubilius R, Gleiznys A, Vitkauskiene A, Ivanauskiene E, Šaferis V, Relationship of clinical and microbiological variables in patients with type 1 
diabetes mellitus and periodontitis. Med Sci Monit., 2014; 20: 1871-1877.

26. Sampaio E, Rocha M, Figueiredo LC, Faveri M, Duarte PM, Gomes Lira EA, Feres M, Clinical and microbiological effects of azithromycin in the treatment of generalized chronic periodontitis: a randomized placebo-controlled clinical trial. $J$ Clin Periodontol., 2011; 38: 838-846.

27. Shaddox LM, Huang H, Lin T, Hou W, Harrison PL, Aukhil I, Walker CB, Klepac-Ceraj V, Paster BJ, Microbiological characterization in children with aggressive periodontitis. J Dent Res., 2012; 91(10): 927-933.

28. Shaikh HFM, Patil SH, Pangam TS, Rathod KV, Polymicrobial synergy and dysbiosis: an overview. J Indian Soc Periodontol., 2018; 22(2): 101-106.

29. Silva MP, Feres M, Sirotto TA, Soares GM, Mendes JA, Faveri M, Clinical and microbiological benefits of metronidazole alone or with amoxicillin as adjuncts in the treatment of chronic periodontitis: a randomized placebo-controlled clinical trial. J Clin Periodontol., 2011; 38: 828-837.

30. Soares GMS, Figueiredo LC, Faveri M, Cortelli SC, Duarte PM, Feres M, Mechanisms of action of systemic antibiotics used in periodontal treatment and mechanisms of bacterial resistance to these drugs. J Appl Oral Sci., 2012; 20(3): 295-309.

31. Socransky SS, Haffajee AD, Teles R, Wennstrom JL, Lindhe J, Bogren A, Hasturk H, van Dyke T, Wang X, Goodson JM, Effect of periodontal therapy on the subgingival microbiota over a 2-year monitoring period. I. Overall effect and kinetics of change. J Clin Periodontol., 2013; 40(8): 771-780.

32. Stokman MA, van Winkelhoff AJ, Vissink A, Spijkervet FK, Raghoebar GM, Bacterial colonization of the peri-implant sulcus in dentate patients: a prospective observational study. Clin Oral Investig., 2017; 21(2): 717-724

33. Tanner ACR, Hadfer C, Bratthal GT, Visconte RA, Socransky SS, A study of the bacteria associated with advancing periodontitis in man. $J$ Clin Periodontol., 1979; 6: 278-307.

34. Valente NA, Andreana S, Treatment of peri-implantitis using a combined decontaminative and regenerative protocol: case report. Compend Contin Educ Dent., 2018; 39(2): $96-101$.

35. Wootton M, Bowker KE, Holt HA, MacGowan AP, BAL 9141, a new broad-spectrum pyrrolidinone cephalosporin: activity against clinically significant anaerobes in comparison with 10 other antimicrobials. $J$ Antimicrob Chemother., 2002; 49(3): 535-539. 